\title{
Development of web-based application in population administration system using scrum framework
}

\author{
Ginanjar Wiro Sasmito* and M. Nishom \\ Lecturer, Department of Informatics Engineering, Politeknik Harapan Bersama, Indonesia
}

Received: 09-November-2019; Revised: 10-January-2020; Accepted: 12-January-2020

(C2020 Ginanjar Wiro Sasmito and M. Nishom. This is an open access article distributed under the Creative Commons Attribution (CC BY) License, which permits unrestricted use, distribution, and reproduction in any medium, provided the original work is properly cited.

\begin{abstract}
There are two methods of collecting population data in Indonesia. These are population census conducted by the Central Bureau of Statistics using data sampling techniques, and recording population data conducted by each resident in the management of Population ID and Family Cards by the Population and Civil Registry Office. The different ways of collecting data, there is great potential demographic data differences in the two institutions; this is a pretty serious problem regarding the validity and accuracy of demographic data. The population data of the two institutions are commonly used as a basis for making policies regarding beneficiaries for the poor, recipients of educational assistance, determining voting rights in elections and etc. The solution provided is the result of this research is, the solution is to produce a website-based computer application platform to record population data by a bottom up method, which can be used by both institutions. The solution given that the result of this research is to produce a web-based computer application platform in order to perform maintenance of the population administration process by taking demographic data in steps / processes bottom up, eventually the population data used by both institutions. The website applications are built by implementing the Scrum framework. This is implemented to speed up the work process compared to other frameworks. Since it only takes 30 days by involving all the Scrum teams. A web application that has been generated has also been tested with usability testing using system usability scale (SUS) method with the results of $=83.5 \%$. This application has been applied to the Department of Population and Civil Registration and Statistics Agency in the area of Tegal city. So, this application is highly recommended to be implemented at the Department of Population and Civil Registration and the Central Bureau of Statistics throughout Indonesia. Since it has made the population data into a single data, valid, accurate and eliminates data redundancy, in addition to demographic data update process has also become faster and in real time.
\end{abstract}

\section{Keywords}

Web applications, Population, Scrum, OAM.

\section{Introduction}

Indonesia is one of the countries with a high level of density and greatly contributes to world population growth [1]. Where in 2017 the population was more than 261 million people spread in 34 provinces with a population growth rate of $1.34 \%$ [2]. Large population growth in Indonesia will occur over the next 25 years, even though the rate of increase will slow down; this is especially occurring on Java even though the area is only $7 \%$ of the land area of Indonesia [3]. Population density can have an impact on several things, such as: distribution of populations close to the coastline will affect the risk of rising sea levels [4], habitat fragmentation [5] and determine the spread of infectious diseases [6].

*Author for correspondence
Besides that fast and uncertain population growth also influence in determining mitigation [7] and change, global policy, such as: land use, energy use, and emissions use [8] therefore, good planning is necessary to minimize or even avoid these impacts, one of the efforts that must be done is to manage population data optimally.

The purposes of managing population data include increasing service effectiveness, ensuring data accuracy, ensuring identity and population documents that are single [9]. To make this purpose to be realized, accurate and real-time data collection techniques are needed, as well as good data integration between population data managers at the central, provincial and city / district levels. 
Classification of population data consists of several things, including: population based on age, sex, occupation, religion, productive age and unproductive age, recent education, and income, it also requires data on population numbers and growth in each region [10], both for the scope of the state, province, and city / regency.

In Indonesia there are two ways of collecting population data, they are population census conducted by the Central Bureau of Statistics using data sampling techniques [11], and recording population data conducted by each resident in the management of population identification and family cards by the population and civil registry office [12]. The different ways of collecting data, there is great potential demographic data differences in the two institutions; this is a pretty serious problem regarding the validity and accuracy of demographic data. The population data of the two institutions are commonly used as a basis for making policies regarding beneficiaries for the poor, recipients of educational assistance, determining voting rights in elections and etc. The Population data available in the two institutions are presented in pdf and table format.

Based on these problems, the solution that can be given is to a website-based computer application platform to carry out the process of taking population data in stages by way of bottom up. namely: the head of the RT (Neighbourhood association) inputs population data with variables that have been determined by the government, then validated by the head of the RW (Neighbourhood association), Village, and District for further validation and verification by the Department of Population and Civil Registration. The validated and verified data from the Office of Population and Civil Registration can be directly taken and utilized by the Central Bureau Statistics as a mutually integrated data and presented with a high validity and accuracy, since data integration is a way to minimize redundancy and duplication of data [13], so the data which is processed or presented is single data. In addition to understand the presented data more easily, the visualization of data in the form of graphs or charts is displayed in the computer application platform as part of the solution to the existing problems. Web application platform which is the result of this research is built using the Scrum framework, this is implemented to speed up the process compared to other frameworks.

\section{Related work}

A research has resulted in a website application which is developed to visualize the macromolecular structures, by utilizing modern web technologies: WebGL or NGL Viewer, which is able to provide scaled molecular graphs. Generally, the resulting web application offers a comprehensive molecular visualization through the user interface, so it can easily access and take advantage of available structural data [14].

A web application that adopts semantic web technology is applied to describe the ontology application management framework; it is called OAM (An ontology application management). The framework focuses on providing data and application templates that can easily be used and configured for users without having expertise in programming. There are three forms of template that have been generated, they are: ontology mapping database configuration, recommendation rules, and application templates. The case studies which are used in the application of the framework are: introduction of the smart home domain activities, and clinical support systems of Thalassemia [15].

In analyzing differential gene expression (DGE) usually uses a variety of devices, such as: statistical software, spreadsheets, or special ad-hoc algorithms. Therefore, in this study a web-based application has been produced with the name: DEIVA Web Application. This application is a freeware and opensource application that allows finding and identifying single or multiple genes quickly, interactively and intuitively. DEIVA is designed for a very large number of users and data sets. Comparing with other software, DEIVA has a unique combination of design decisions that allow inspecting and analyzing to DGE statistical test results with user friendly features [16].

Web applications are also applied in estimating carbon footprint in organic agriculture. Organic farmers often use complex management practices in encouraging positive impacts on the environment. While many tools have been used in estimating environmental use, but only a few are able to handle the complexities of organic farming as well. Therefore, an online web application has been developed called Ofoot which has been implemented in the Pacific Northwest to estimate the carbon footprint of organic agriculture and assist to evaluate the potential environmental benefits. Ofoot uses a cradle-to-gate carbon calculator and biophysical models based on the process of planting and 
environmental management. Ofoot serves as an aid for management decisions in organic farming [17].

A web application has also been developed to estimate the total cost in electric discharge from experimental parameters set in the reactor such as: JUPITER-MOSMET [1-5], which is used to modify metal and non-metal surface types in solid substrates by high-voltage hybrid electric discharge and low pressure [6-13]. The developed web application can be used anytime, anywhere and without special requirements, it only requires an internet connection and current pulse data to be processed. Format data received by the system can be downloaded via the web application. Processing data obtained from the web application is very similar to the current pulses that are reported experimentally during the ignition of electricity, to ensure that the implemented web application works properly and correctly to estimate the total cost [18].

The application of the web application is also carried out for analytical visualization of smart city applications. In this study 4D canvas models and web-based applications have been produced for dynamic visualization of 3D geospatial data for better decision making in smart city applications. The 4D canvas in this study can be used both on desktop and multi-touch screens, platforms; this application also allows easier integration of other geospatial simulation results, thus helping users explore interactively in 4D [19].

\section{Methodology}

The dataset used in this study is from the city of Tegal, Indonesia with the classification of: population based on age, sex, occupation, religion, productive age and unproductive age, last education, and income, besides that data is also needed the number and population growth in each region, both villages or district areas.

The dataset is used for developing web applications that are applied to the population administration system in this study using the Scrum framework. The scrum was developed by Jeff Sutherland in 1993 with the aim of becoming a development and management methodology that follows the principles of the Agile methodology [20]. A scrum is a framework which is used for software development projects and managing the product or application development [21].
Scrum focuses on flexible strategies for developing software products, where the development team works to achieve common goals [22]. Scrum has a complex process, in which many factors influence the final result [23]. The scrum framework consists of product guarantees, sprint planning meetings, sprint backlogs, sprint retrospectives, sprint reviews, and daily meetings which are conducted by team members to complete the project [24], while the intended team members are: product owner, development team and Scrum Masters [25]. In this study the Scrum framework scheme that is applied can be shown in the following Figure 1 [26]:

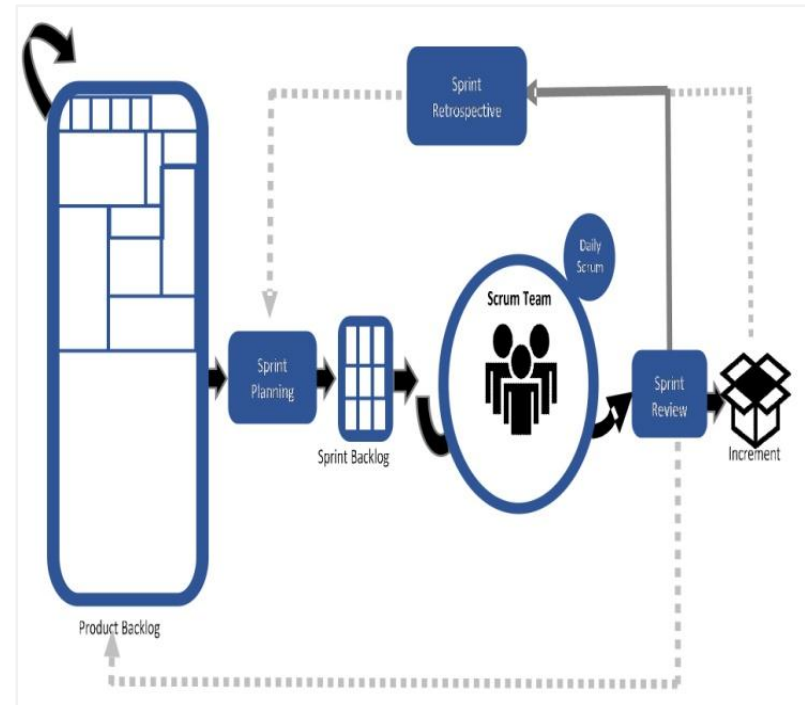

Figure 1 Scrum framework

\section{Result and discussion 4.1Web design}

The design of web application development in population administration systems is made by using UML (Unified Modeling Language) which is a standard for designing object-oriented systems with a high level of complexity [27]. UML is used to determine, visualize, build and do documentation when establishing / developing application systems using certain programming languages [28]. In this study UML diagrams are illustrated using Use case diagram. This diagram is functionality provided by the system as a unit for interacting each other between units or actors [29] and Class Diagrams, in which are diagrams with static structures that able to illustrate the structure of a system by showing system classes, attributes, operations (methods), and relationships between objects [30]. Figure 2 shows the use case diagram. Figure 3 shows the class diagram. 


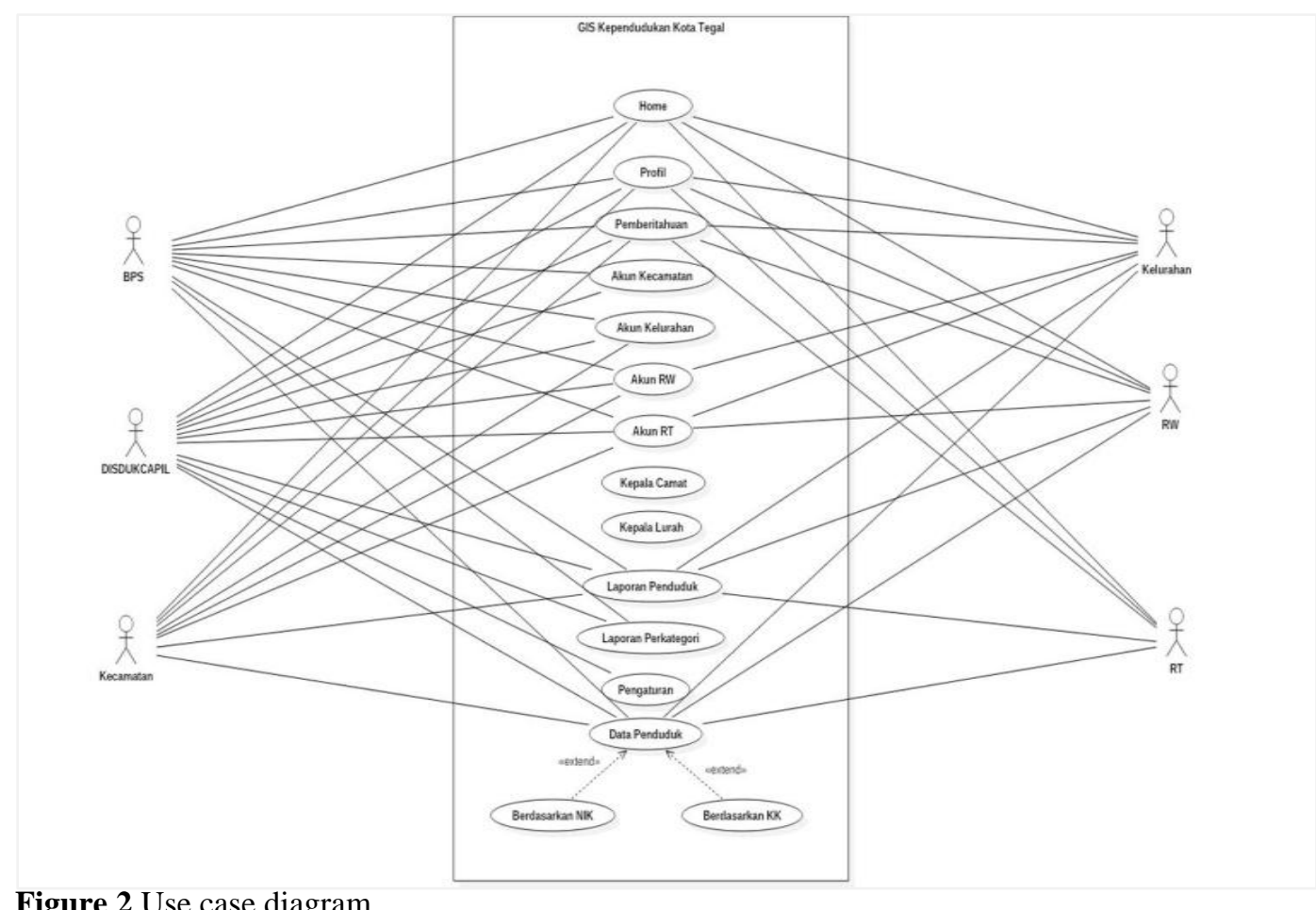

Figure 2 Use case diagram

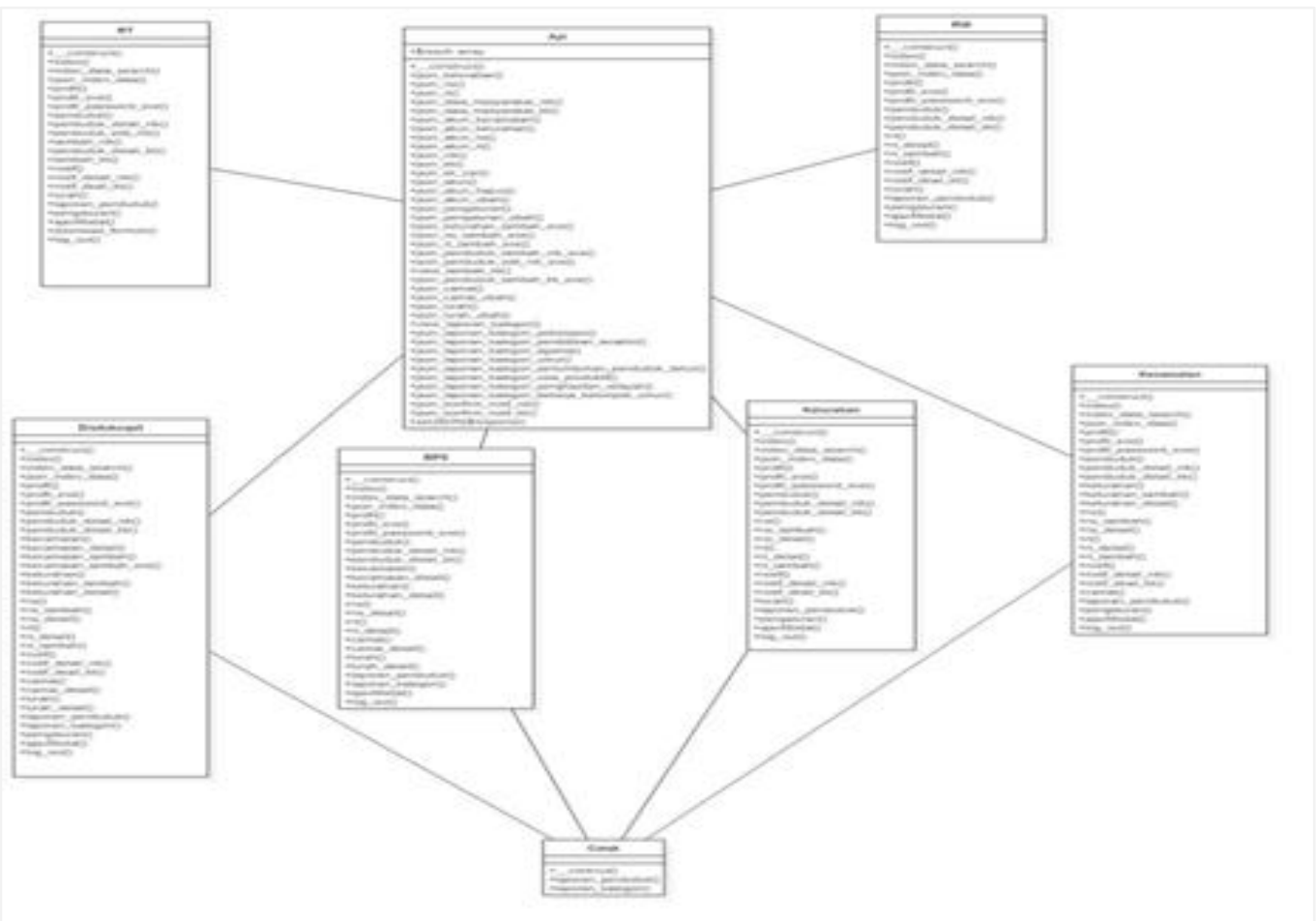

Figure 3 Class diagram 


\subsection{User interface}

The user interface of a web application that has been generated in this study is used for 6 administrator menus, such as menus for head of RT, head of RW, village office, sub-district, Department of Population and Civil Registration, and Central Bureau of Statistics. The web application is developed using the
PHP programming language which is a server-side script programming language, it is designed for web development [31] with a database in the form of My SQL which is an open source relation database management system (RDBMS) [32]. The user interface can be seen in Figure 4 below:

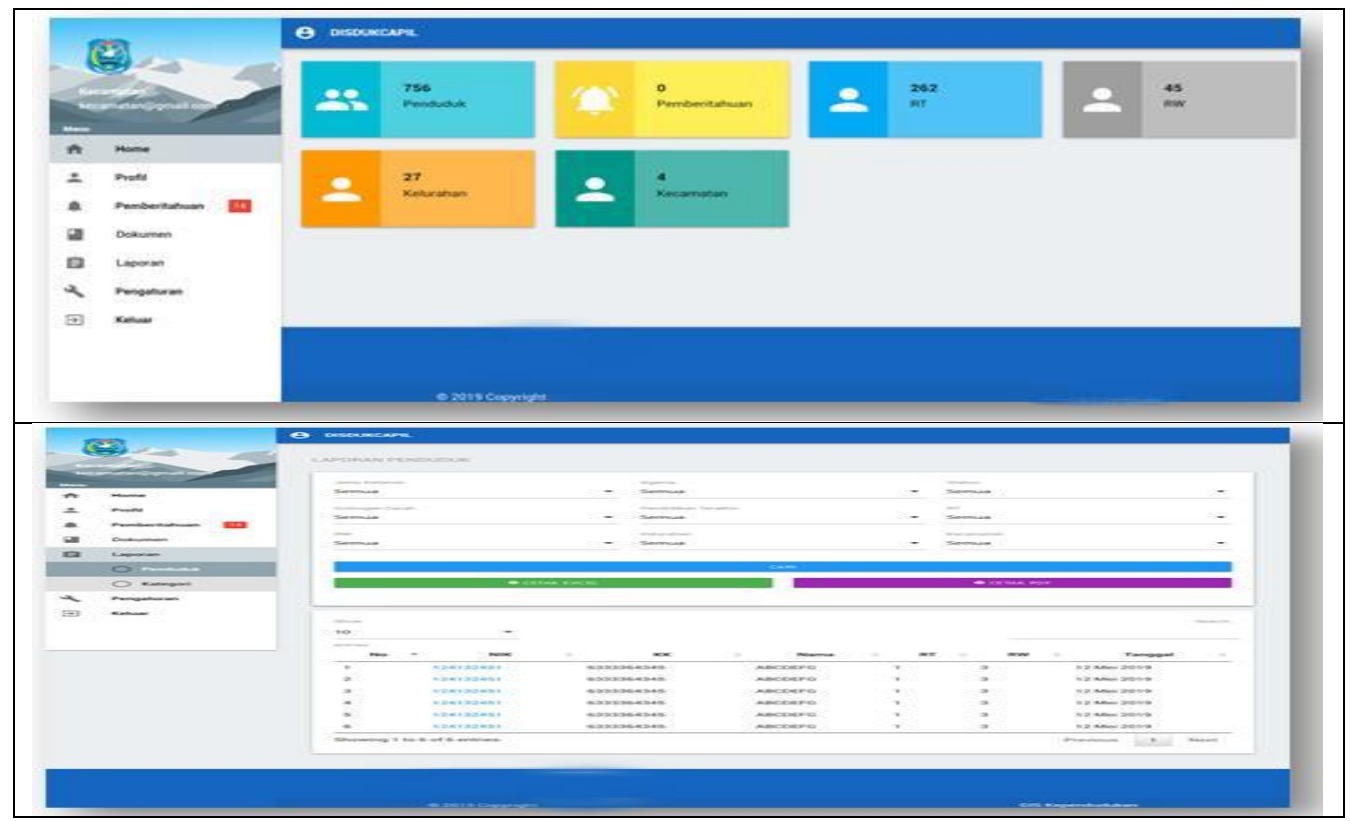

Figure 4 Display of web application

\subsection{Discussion}

The development of a population administration web application is carried out with the Scrum framework, the explanation is as follows:

\section{a.Product backlog}

Product Backlog is a list of all the features, functions, needs, enhancements, and improvements that need to be applied to a product. Product Backlog aims to determine priority work in a sprint; this is determined by the Product Owner, Scrum Master, and Development Team. Product Backlog has to be conducted and has been arranged according to certain priorities. These items can be in the form of the results and exploration of customer needs, functional and non-functional descriptions, as well as the things needed to release a finished product [33]. The Product Backlog is the responsibility of the product owner with the following details in Table 1:

The Product Backlog in Table 1 shows the priority order of work in the Scrum framework, where the work can be accomplished in 30 days.

Table 1 Product backlog

\begin{tabular}{|c|c|c|c|}
\hline ID & Product backlog item & Priorization & Estimate (Day) \\
\hline 1 & Problem Identification and Analysis & & 1 \\
\hline 2 & Description of Solution & & 1 \\
\hline 3 & Identification of Needs & & 1 \\
\hline
\end{tabular}




\begin{tabular}{|c|c|c|c|}
\hline ID & Product backlog item & Priorization & Estimate (Day) \\
\hline 4 & $\begin{array}{l}\text { System Design and Prototyping } \\
\text { (UML Design, UI / UX Design) }\end{array}$ & & 3 \\
\hline 8 & $\begin{array}{l}\text { Testing } \\
\text { (Software Testing using Black Box and White Box } \\
\text { Testing) }\end{array}$ & & 1 \\
\hline 9 & $\begin{array}{l}\text { Testing } \\
\text { (Usability Testing) }\end{array}$ & & 1 \\
\hline 5 & $\begin{array}{l}\text { Database Design and Creation } \\
\text { (Database Design and Creation with My SQL using } \\
\text { XAMPP) }\end{array}$ & & 5 \\
\hline 7 & $\begin{array}{l}\text { System-wide integration } \\
\text { (Integration of web application systems using databases, } \\
\text { and integration between administrator menus) }\end{array}$ & & 3 \\
\hline 6 & $\begin{array}{l}\text { Coding in creating applications (Building a web } \\
\text { application with the PHP programming language in } \\
\text { accordance with the existing design and prototype) }\end{array}$ & & 10 \\
\hline 10 & $\begin{array}{l}\text { Application improvements and refinements } \\
\text { (After going through the process of integration and testing, } \\
\text { then the web application is repaired and refined to avoid } \\
\text { bugs / errors and to suit the needs of the product owner) }\end{array}$ & & 3 \\
\hline 11 & $\begin{array}{l}\text { Release } \\
\text { (After the application has been integrated, tested, then } \\
\text { repaired / refined based on the needs of the product owner } \\
\text { and the product has been documented in according to the } \\
\text { initial agreement, then the web application can be released) }\end{array}$ & & 1 \\
\hline Total & & & 30 \\
\hline
\end{tabular}

\section{b.Sprint planning}

At this stage the tasks that will be conducted in the web application development project are formulated in a task meeting that will be carried out by the whole team, they are: the product owner, scrum master, and development team. The division of tasks and the flow can be explained in the following Table 2

\section{c.Sprint backlog}

The Sprint Backlog is an estimation of the functionality that will be available in the next iteration, and an important task that needs to be conducted to deliver the functionality into pieces of product that are considered complete [34]. At this stage, the development team creates a picture of the real project that is being worked on, in accordance with the plan of product owner at the product backlog stage. This stage is conducted every time will do a sprint.

\section{d.Daily scrum}

Daily Scrum is a stage when all members of the development team share the problems experienced and provide solutions to each other's problems, the Team also shares the results / progress of their work, including design and prototype of the application, database design and manufacturing, coding / programming, application integration, application testing, and application improvement / refinement. Daily scrum is carried out every day during the sprint.

\section{e.Sprint review}

Sprint review a stage when every team member demonstrates the results of his / her work in a sprint. This stage is carried out after one sprint is completed. In this case all the team members demonstrate the project development of population administration 
web applications and evaluate each other then finally all team members' works are united and integrated.

Table 2 Sprint planning meeting

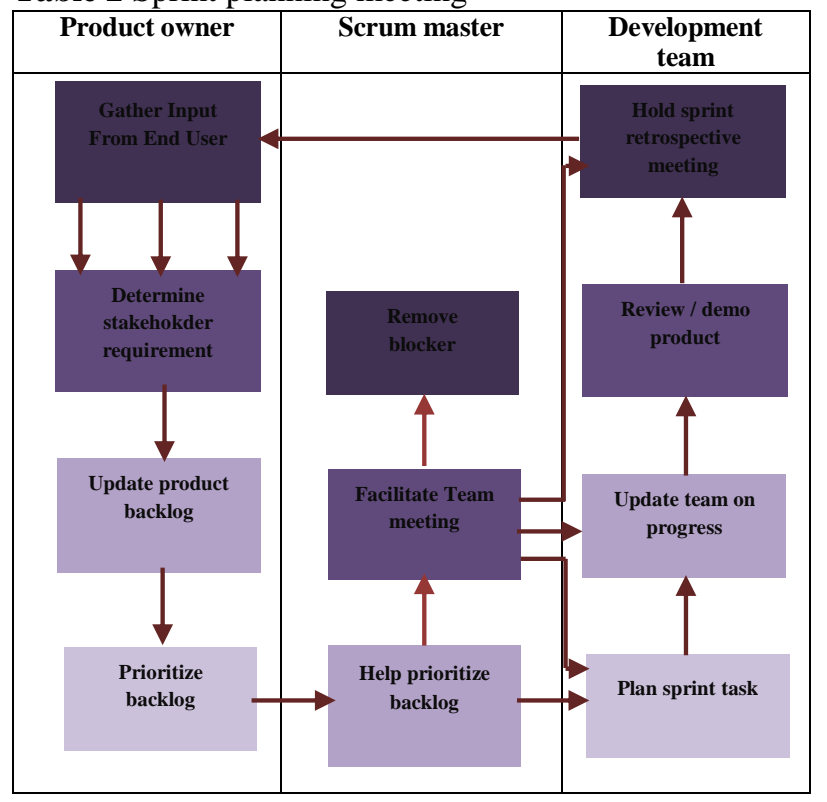

\section{f.Sprint retrospective}

The Sprint Retrospective is conducted at the end of each sprint. At this stage, the development team presents to the product owner and scrum master about the scrum process that is being implemented in developing a population administration web application. The development team also presents the testing results of population web application using black box and white box and presents the user testing results using usability testing as a product evaluation technique with verifying to users [35]. There are five elements that are the main elements of usability testing. They are usability, efficiency, effectiveness, satisfaction and accessibility [36]. The test is conducted by distributing the questionnaire randomly to head of RT, head of RW, village office employees, sub-district employees, Department of Population and Civil Registration employees, Central Bureau of Statistics employees, academics, and IT practitioners with a total of 8 respondents with 7 questions in which previously they are asked to use a web application according to the account provided.

Table 3 Calculation of respondents score

\begin{tabular}{|c|c|c|c|c|c|c|c|c|c|c|}
\hline \multirow{2}{*}{ No } & \multirow{2}{*}{ Question } & \multicolumn{8}{|c|}{ Respondents' score (R) } & \multirow{2}{*}{ Score } \\
\hline & & R1 & $\mathbf{R 2}$ & R3 & R4 & R5 & R6 & R7 & R8 & \\
\hline 1. & Q1 & 4 & 5 & 5 & 5 & 5 & 3 & 5 & 5 & 37 \\
\hline 2. & $\mathrm{Q} 2$ & 4 & 4 & 3 & 4 & 4 & 4 & 4 & 5 & 32 \\
\hline 3. & Q3 & 4 & 5 & 4 & 5 & 4 & 4 & 5 & 3 & 34 \\
\hline 4. & $\mathrm{Q} 4$ & 4 & 4 & 3 & 3 & 4 & 3 & 4 & 4 & 29 \\
\hline 5. & Q5 & 4 & 5 & 4 & 4 & 4 & 5 & 5 & 4 & 35 \\
\hline 6. & Q6 & 4 & 3 & 4 & 3 & 3 & 5 & 3 & 4 & 29 \\
\hline 7. & Q7 & 4 & 5 & 5 & 5 & 4 & 5 & 5 & 5 & 38 \\
\hline \multicolumn{10}{|c|}{ Total } & 234 \\
\hline
\end{tabular}

The conversion results of the total score in Table 3 are shown in the percentage; they are calculated by dividing total score to total maximum score of $x$ 100\%:

$$
\begin{aligned}
\text { Percentage } & =\quad \frac{234}{280} \times 100 \% \\
& =83,5 \%
\end{aligned}
$$

The measuring instruments used are SUS (System Usability Scale) questionnaires. The result can be calculated by using formula:

$\mathrm{Y}=\mathrm{Q} / \mathrm{S} \times 100 \%$

$\mathrm{Q}=$ Total scores of respondent for each question

$\mathrm{S}=$ Total Maximum of respondent's scores

$\mathrm{Y}=$ Percentage Score

Then the average SUS scale calculation results for all distributed questions obtains a score $=83.5 \%$
After usability testing is complete, the product owner and scrum master provide suggestions and criticisms relating to the team's performance in implementing Scrum. Then the development team improves and perfects the population administration web application based on test results and suggestions from the product owner and scrum master.

\section{g.Increment}

The increment is the last step of the Scrum Framework. This stage is a result of completed work to support empiricism and it is can be inspected at the end of the Sprint. In this case the sprint result, increment is a step to achieve the goal / vision. This stage the product owner also decides whether the project has been completed or not. 
The development of population administration web applications can be quickly resolved, because all Scrum teams are involved, so application development only takes 30 days to implement. This is clearly faster than developing the population profile web owned by the Tegal city government, which is developed using the waterfall method and takes up to 1 year to complete the web platform [37].

\section{Conclusion}

Based on the results of the completed research, it can be concluded that the process of developing a population administration web application using the Scrum framework only takes 30 days. This is faster when it is compared to the population profile web owned by the Tegal city government, which is developed with the waterfall method and takes up to 1 year to complete the web platform. So, the population administration web application is highly recommended to be applied to the Population and Civil Registry Office and the Central Bureau Statistics throughout Indonesia. The use of the Scrum framework is faster because all Scrum teams are involved in the process of completion. So, that data and applications can be integrated properly, the problems during application development is also quicker to be solved. The product of web application makes population data into a single data and eliminates data redundancy. Besides that, the process of updating the population data also becomes fast and real time. The result of the usability testing using SUS is $83.5 \%$.

\section{Acknowledgment}

Author would like to thank the Department of Population and Civil Registration and Central Bureau of Statistics Tegal City for sharing data source and Ministry of Technology Research and Higher Education of Indonesia for Funding this Research.

\section{Conflicts of interest}

The authors have no conflicts of interest to declare.

\section{References}

[1] https://www.copenhagenconsensus.com/publication/in donesia-perspectives-population-and-demography. Accessed 15 June 2019.

[2] https://www.bps.go.id/publication/2018/07/03/5a963c 1ea9b0fed6497d0845/statistik-indonesia-2018. Accessed 15 June 2019.

[3] Jones GW. The 2010-2035 Indonesian population projection: understanding the causes, consequences and policy options for population and development. Jakarta, Indonesia: United Nations Population Fund Indonesia. 2015.
[4] McGranahan G, Balk D, Anderson B. The rising tide: assessing the risks of climate change and human settlements in low elevation coastal zones. Environment and Urbanization. 2007; 19(1):17-37.

[5] Theobald DM, Crooks KR, Norman JB. Assessing effects of land use on landscape connectivity: loss and fragmentation of western US forests. Ecological Applications. 2011; 21(7):2445-58.

[6] Caminade C, Kovats S, Rocklov J, Tompkins AM, Morse AP, Colón-González FJ, et al. Impact of climate change on global malaria distribution. Proceedings of the National Academy of Sciences. 2014; 111(9):3286-91.

[7] Scovronick N, Budolfson MB, Dennig F, Fleurbaey M, Siebert A, Socolow RH, et al. Impact of population growth and population ethics on climate change mitigation policy. Proceedings of the National Academy of Sciences. 2017; 114(46):12338-43.

[8] Jones B, O'Neill BC. Spatially explicit global population scenarios consistent with the shared socioeconomic pathways. Environmental Research Letters. 2016; 11(8):1-10.

[9] Stephens M, Smith NJ, Donnelly P. A new statistical method for haplotype reconstruction from population data. The American Journal of Human Genetics. 2001; 68(4):978-89.

[10] Willems T, Gymrek M, Poznik GD, Tyler-Smith C, Erlich Y, 1000 Genomes project chromosome Y group. Population-scale sequencing data enable precise estimates of Y-STR mutation rates. The American Journal of Human Genetics. 2016; 98(5):919-33.

[11] https://www.bps.go.id/. Accessed 15 June 2019.

[12] https://m.hukumonline.com/pusatdata/detail/26195/no de/758/undangundang-nomor-23-tahun-2006.

Accessed 15 June 2019.

[13] Kang TW, Hong CH. A study on software architecture for effective BIM/GIS-based facility management data integration. Automation in Construction. 2015; 54:2538.

[14] Rose AS, Hildebrand PW. NGL viewer: a web application for molecular visualization. Nucleic Acids Research. 2015; 43(W1): W576-9.

[15] Buranarach M, Supnithi T, Thein YM, Ruangrajitpakorn $\mathrm{T}$, Rattanasawad $\mathrm{T}$, Wongpatika seree $\mathrm{K}$, et al. OAM: an ontology application management framework for simplifying ontologybased semantic web application development. International Journal of Software Engineering and Knowledge Engineering. 2016; 26(01):115-45.

[16] Harshbarger J, Kratz A, Carninci P. DEIVA: a web application for interactive visual analysis of differential gene expression profiles. BMC Genomics. 2017:1-5.

[17] Carlson BR, Carpenter-Boggs LA, Higgins SS, Nelson R, Stöckle CO, Weddell J. Development of a web application for estimating carbon footprints of organic farms. Computers and Electronics in Agriculture. 2017; 142:211-23. 
[18] Vera-Rivera FH, Dugar-Zhabon VD, Dulce-Moreno HJ, V-Niño ED. Development of a web application for estimate the total charge in an electric discharge. In journal of physics: conference series 2016 (pp. 1-4). IOP Publishing.

[19] Murshed S, Al-Hyari A, Wendel J, Ansart L. Design and implementation of a 4D web application for analytical visualization of smart city applications. ISPRS International Journal of Geo-Information. 2018; 7(7):1-18.

[20] Pham A. Scrum in action: agile software project management and development. Cengage Learning; 2011.

[21] Permana PA. Scrum method implementation in a software development project management. International Journal of Advanced Computer Science and Applications. 2015; 6(9):198-204.

[22] Mariyappan S, Abdullah NL, Idrus R. Enhancing scrum framework: a case at a multinational manufacturing company in Malaysia. International Journal of Engineering \& Technology. 2018; 7:198203.

[23] Qureshi MR, Sayid I. Scheme of global scrum management software. International Journal of Information Engineering and Electronic Business. 2015; 7(2):1-7.

[24] Pino FJ, Pedreira O, García F, Luaces MR, Piattini M. Using scrum to guide the execution of software process improvement in small organizations. Journal of Systems and Software. 2010; 83(10):1662-77.

[25] https://www.scrumstudy.com/sbokguide/sbokguidevs-other-scrumbooks?. Accessed 15 June 2019.

[26] David M. Scrum: an ideal framework from agile project in easy step. Easy Steps Ltd. 2017.

[27] Bashir RS, Lee SP, Khan SU, Chang V, Farid S. UML models consistency management: guidelines for software quality manager. International Journal of Information Management. 2016; 36(6):883-99.

[28] Ho-Quang T, Hebig R, Robles G, Chaudron MR, Fernandez MA. Practices and perceptions of UML use in open source projects. In international conference on software engineering: software engineering in practice track 2017 (pp. 203-12). IEEE.

[29] Torre D, Labiche Y, Genero M, Baldassarre MT, Elaasar M. UML diagram synthesis techniques: a systematic mapping study. In international workshop on modelling in software engineering 2018 (pp. 3340).
[30] Sparks G. Database modelling in UML. Methods \& Tools. 2001; 9(1):10-23.

[31] https://www.goodreads.com/book/show/46771798php. Accessed 30 October 2019.

[32] Mehta C, Bhavsar A, Oza H, Shah S. MySQL 8 administrator's guide. 2018.

[33] Pichler R. Agile product management with scrum: creating products that customers love. Pearson Education India; 2010.

[34] Deemer P, Benefield G, Larman C, Vodde B. A lightweight guide to the theory and practice of scrum (version 2.0). Technical Report. 2012.

[35] Andreasen MS, Nielsen HV, Schrøder SO, Stage J. What happened to remote usability testing?: an empirical study of three methods. In proceedings of the SIGCHI conference on human factors in computing systems 2007 (pp. 1405-14). ACM.

[36] Rubin J, Chisnell D. Handbook of usability testing: how to plan, design and conduct effective tests. John Wiley \& Sons; 2008.

[37] https://disdukcapil.tegalkota.go.id/. Accessed 30 October 2019.

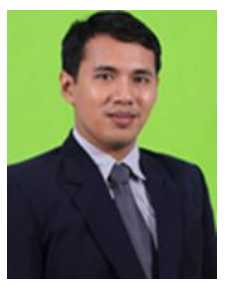

Ginanjar Wiro Sasmito is a Lecturer in Department of Informatic Engineering, Politeknik Harapan Bersama, Indonesia. He received his Master of Computer degree from Diponegoro University, Indonesia, in 2010. His research interest in Information System, E- Business and ERP. He has published several papers in international journals and conferences.

Email: anjar.dosen@gmail.com

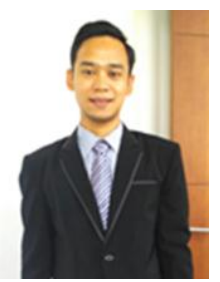

M. Nishom is a Lecturer in Department of Informatic Engineering, Politeknik Harapan Bersama, Indonesia. $\mathrm{He}$ received his Master of Computer degree From Diponegoro University, Indonesia. His research interest in Software Engineering and Data Mining. He is manager and person in charge of the software engineering laboratory in Politeknik Harapan Bersama.

Email: m.nishom.undip@gmail.com 